\title{
First epidemiological study on exposure to Neospora caninum in different canine populations in the Algiers District (Algeria)
}

\author{
F. Ghalmi a,b, B. China ${ }^{\text {c }}$, R. Kaidi ${ }^{\text {d, }}$, B. Losson ${ }^{\text {a,* }}$ \\ a University of Liege, Faculty of Veterinary Medicine, Department of Infectious Diseases, Laboratory of Parasitology, Sart Tilman B43, B-4000 Liège, Belgium \\ ${ }^{\mathrm{b}}$ National Veterinary School of Algiers, MB 161 Hassen Badi El-Harrach, Algiers, Algeria \\ c Scientific Institute of Public Health, Epidemiology and Toxicology Department, rue J. Wytsman, 14, 1050 Brussels, Belgium \\ d University Saad Dahlab of Blida, Veterinary Sciences Department, Blida, Algeria
}

\section{A R T I C L E I N F O}

\section{Article history:}

Received 7 May 2009

Received in revised form 21 August 2009

Accepted 24 August 2009

Available online 29 August 2009

\section{Keywords:}

Neospora caninum

Dogs

Seroprevalence

Real time PCR-Algeria

\begin{abstract}
A B S T R A C T
Neospora caninum is an important cause of abortion in cattle worldwide. Dogs act as final hosts shedding oocysts in the environment. They can also harbour the extraintestinal stage of the parasite and this may be associated with a fairly rare neuromuscular condition. The sera of 781 dogs from the Algiers District were screened by IFAT for the presence of anti-N. caninum antibodies. These dogs were distributed into four populations: local stray dogs, police dogs, dogs from breeding kennels and farm dogs. The overall seroprevalence was $21.90 \%$. Significant differences were observed between the different populations, the highest prevalence being observed in farm (44.44\%) and stray dogs (22.55\%). Additionally, the highest titres were observed in farm dogs. Among studied epidemiological parameters, breed, dog origin, season and vaccination status were significantly associated with IFAT results. Additionally, a recently described real time PCR was used on the blood of 100 pound dogs and the results were compared with the serological data. A higher proportion of dogs was found to be positive by PCR when compared to the IFAT results. There was only a fairly low agreement between PCR and IFAT results which suggests that these techniques measured different aspects of the host-parasite relationship. This study indicates that the level of exposure of the canine population of Algiers area to $N$. caninum is very high. This would indicate a potentially high risk for $N$. caninum induced abortion in cattle in this region and in Algeria.
\end{abstract}

(C) 2009 Elsevier Ireland Ltd. All rights reserved.

\section{Introduction}

Neospora caninum is an Apicomplexa protozoan responsible for abortion in cattle worldwide [1]. In dogs it can be responsible for a severe disease characterised by various clinical signs, including limb ataxia, ascending paralysis and generalised neurological signs [2]. It can also induce myocardial, pulmonary and dermal lesions [3].

In cattle, the parasite can persist over several generations in breeding units $[4,5]$, which serve as a reservoir for Neospora-infections of canids [6]. Dogs (Canis familiaris) are important in the epidemiology of $N$. caninum infection, as they act, together with coyotes (Canis latrans), as definitive hosts shedding $N$. caninum oocysts in the environment [7].

Several previous seroepidemiologic studies reported a positive relationship between the presence of dogs and $N$. caninum induced abortion in cattle $[6,8,9]$.

Additionally several serological surveys demonstrated that dogs originating from dairy farms, with or without a history of abortion in cattle, had higher seroprevalences than those living in urban areas $[6,10,11]$.

\footnotetext{
* Corresponding author. Tel.: +32 436640 90; fax: +32 43664097 . E-mail address: blosson@ulg.ac.be (B. Losson).
}

In healthy dogs, the seroprevalence can be as high as in clinically affected dogs suggesting that infection by $N$. caninum in the dog is most of the time asymptomatic [12].

$N$. caninum has a worldwide distribution and the presence of specific antibodies is frequently reported in healthy dogs and cattle [13]. Several serological techniques including enzyme-linked immunosorbent assays (ELISA) [14], direct agglutination tests (DAT) [15] and indirect fluorescence antiboby test (IFAT) [16] are available. Different studies performed in different hosts demonstrated that IFAT exhibited very little cross-reactivity with other coccidian and noncoccidian parasites [2,17-19]. Consequently, the IFAT is often used as a reference serological test for the detection of $N$. caninum antibodies $[2,19,20]$. More recently, classical, nested, semi-nested and real time PCR were developed to detect the presence of $N$. caninum in dogs' organs [21].

Some studies investigated the seroprevalence in different dog populations in North America [22], in South America [23-26], in Asia $[10,27,28]$, Oceania [29] or Europe [6,30-32].

The present study was the first investigation in North Africa to determine the seroprevalence to $N$. caninum in several dog populations in the Algiers District of Algeria. Some parameters of epidemiological importance (age, sex, breed, vaccination status, general appearance) were also evaluated. A real time PCR technique was used 
to detect $N$. caninum in canine blood as an additional tool to serology. The results obtained with these two techniques were compared.

\section{Materials and methods}

\subsection{Dog populations}

Four dog populations from the Algiers District (Wilaya) (Fig. 1) were investigated. The first group consisted in stray dogs (mainly mongrels) from the city pound (located at Bir Mourad Rais). In this group, sera were collected between 2004 and 2006 twice a week from variable numbers of available dogs. In total, 337 dogs were sampled. Ninety one blood samples were obtained from the second group (dogs belonging to the police squad located in Ain Bainian) during 2004. Group 3 comprised 209 dogs from different breeding kennels around Algiers. Most of them were examined between 2004 and 2007 at the National Veterinary School of Algiers or by city veterinarians. Finally, group 4 comprised 144 dogs from 76 cattle farms of the Algiers District were collected in 2007. When available, epidemiological information about the origin, sex, age, breed, vaccination status or general condition was collected. Only 14 (1.9\%) dogs presented clinical signs compatible with neosporosis (mainly limbs paresis or ulcerous cutaneous lesions): 3 in group 1, 3 in group 2 and 8 in group 3. Group 2 and 3 dogs had been vaccinated against parvovirus infection, viral hepatitis, distemper (NobivacDHP, Intervet, France), leptospirosis (NobivacLepto, Intervet, France) and rabies (Nobivac Rabies, Intervet, France).

Blood samples were taken from the cephalic vein. The clotted blood was centrifuged at $1000 \mathrm{~g}$ for $15 \mathrm{~min}$ and the serum was collected and stored at $-20^{\circ} \mathrm{C}$ until further use.

The general clinical status of the dogs was evaluated by visual examination and palpation. The animals were classified in three grades: bad, average and good.

\subsection{IFAT}

Sera were tested for the presence of specific antibodies against $N$. caninum by the indirect fluorescent antibody test (IFAT) as described by Trees et al. [19], using cell culture-derived tachyzoites of the NC-1 isolate [16] as antigen.

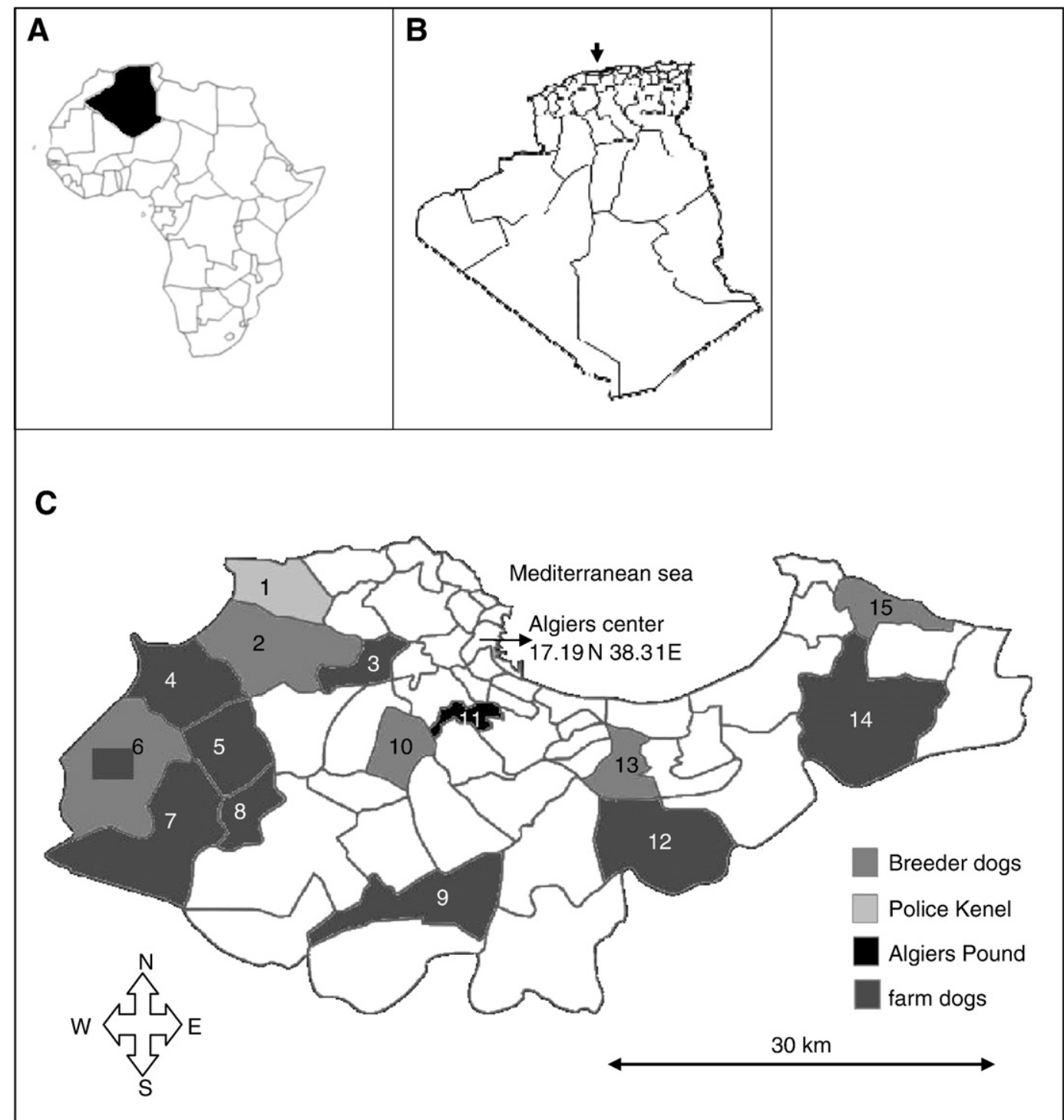

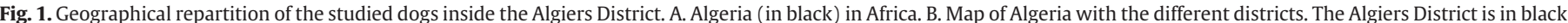

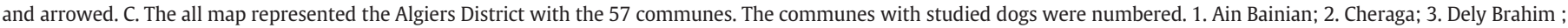

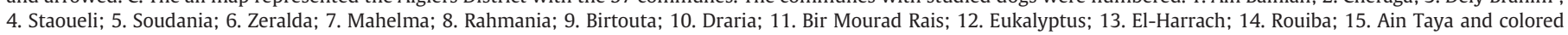
(see legend). 
Briefly, NC-1 tachyzoites were used to infect vero cells (ATTC CRL1587) according to Dubey et al. [16]. When the appropriate level of cell lysis was reached, the entire culture flask content was centrifuged $(1500 \mathrm{~g} 20 \mathrm{~min})$ and the pellet was resuspended in phosphate buffered saline (PBS, pH 7.4) and passed through a 25 gauge-needle in order to lyse the remaining Vero cells. The tachyzoites were harvested by centrifugation ( $1500 \mathrm{~g}$ for $20 \mathrm{~min}$ ). Then the pellet was resuspended in PBS ( $\mathrm{pH} 7.4$ ) and the concentration of tachyzoites was determined using a haemocytometer. Next, $10^{4}$ tachyzoites per well were used to coat 10-well tefloned slides. The slides were dried and $20 \mu \mathrm{l}$ of sera diluted (1:50 to $1: 1600)$ in PBS-BSA 1\% (Phosphate Buffered Solution pH 7.4 containing 1\% Bovine Serum Albumin) was added to the wells for $25 \mathrm{~min}$ at $37^{\circ} \mathrm{C}$. After washing, a FITCconjugated anti-dog IgG (Sigma Aldrich, Saint Louis, USA) diluted 1:64 was added and incubated as above. After a final wash the slides were mounted and positive tachyzoites were looked for under a Zeiss epifluorescence microscope (Laborlux S, Leitz S.A., Van Hopplynus, Belgium) under a $\times 400$ magnification. On each slide a positive and a negative control was used. Positive control sera were obtained from dogs experimentally infected with $N$. caninum and negative control sera were collected from seronegative SPF dogs [30]. The selected cut off was 1:50 [33]. Positive samples were further endtitrated using two-fold serial dilutions. A sample was considered as positive when the whole tachyzoite surface was labelled [16].

\subsection{ELISA}

The serum of 615 dogs from 3 populations (337 stray dogs, 91 police dogs and 187 breeder dogs) has been tested using the BioX SRS2 sandxwich ELISA as previously described [34].

\subsection{Immunoblot}

The immunoblot on dog sera was adapted from the protocol described previously for bovine sera [35]. NC-1 tachyzoites $\left(10^{7} / \mathrm{ml}\right)$ were thawed from liquid nitrogen and centrifuged at $1500 \mathrm{~g}$ for $10 \mathrm{~min}$. The pellets were resuspended in $300 \mu \mathrm{l}$ of $2 \times$ Laemmli sample buffer (Biorad, Nazareth, Belgium) containing $5 \%$ beta-mercaptoethanol. The soluble proteins were denaturated for $3 \mathrm{~min}$ by heating at $100{ }^{\circ} \mathrm{C}$ before loading with a molecular weight marker (Kaleidoscope Prestained Standard, Biorad) on a 12\% SDS PAGE gel. The electrophoresis was performed for 90 min under $200 \mathrm{~V}$ using Tris glycine buffer (Biorad) in a miniprotean 3 cell (Biorad). The proteins were then electro-transferred (Trans-Blot SD, Biorad) on a membrane (Immobilon-P) using CAPS buffer (10 mM CAPS pH 11). The membrane was blocked for $1 \mathrm{~h}$ in PBS containing $5 \%$ skimmed milk (PBS-SM). The blocked membrane was cut into $5 \mathrm{~mm}$-wide strips. Each strip was incubated overnight in test serum sample diluted 100× in PBS-SM. The membranes were washed three times for $5 \mathrm{~min}$ in PBS 0.1\%Tween 20. The washed membrane was incubated with a rabbit anti-dog IgG horseradish peroxydase conjugate (Sigma Aldrich A6792) diluted $1: 2000$. After washing, the presence of fixed conjugate was revealed using a 0.06\% 3,3'-diaminobenzidine (Sigma Aldrich) and 0.02\% hydrogen peroxide solutions. The molecular weight of the revealed bands was estimated using the molecular weight marker containing the following proteins: Myosin (200 kDa), Beta-galactosidase (116 kDa), BSA (66 kDa), Carbonic anhydrase (31 kDa), Soybean trypsin inhibitor (21.5 kDa), Lysozyme (14.4 kDa) and Aprotinin $(6.5 \mathrm{kDa})$.

\subsection{Real time $P C R$}

The DNA was extracted from whole blood using a commercial kit (GFX genomic blood DNA purification kit, Amersham Biosciences). The real time PCR previously described [21] was applied on $5 \mu \mathrm{l}$ of DNA preparation. This PCR consisted in the amplification of the NC-5 loci with a detection of the amplicon using a specific Taqman ${ }^{\mathrm{TM}}$ probe. The cycle number was 50. A negative extraction control was included and consisted of canine blood demonstrated previously as PCR negative [21]. A specificity control consisted in Toxoplasma gondii DNA (x copies/ml) (QCMD, Scotland). A standard curve was constructed using dilutions of pure DNA from NC-1 tachyzoites. This standard curve was used to determine the amount of genomeequivalent per $\mathrm{ml}$ of blood. Since this PCR system used an Internal PCR control, a PCR inhibition can be detected. In such a case, the DNA was diluted 10 times and the PCR was performed again.

\subsection{Statistics}

The prevalence data were analysed using the uncorrected chisquare test or Fisher exact test with significance defined as a $p$-value of $\leq 0.05$ using Instat 3 software (Graphpad software, San Diego, USA). The Kappa Cohen values, the specificity and the sensitivity were calculated using the Winepiscope 2.0 software.

\section{Results}

\subsection{Seroprevalence}

The seroprevalence data are summarised in Table 1 . The overall prevalence of $N$. caninum in dogs based on IFAT was $21.72 \%$. Significant differences $(p<0.001)$ were observed among the different populations. Indeed, the prevalence was the lowest in group 2 (police squad) $(6.59 \%)$ and 3 (kennel) dogs $(11.57 \%)$ whereas higher values were observed in group 4 (farm) (44.44\%) and 1 (pound) $(22.61 \%$ ) dogs. This indicated a significant population effect on N. caninum.

In group 1 (pound dogs), serological data were available from 3 consecutive years (from 2004 to 2006). Therefore, the seroprevalences were compared on a yearly basis. The annual seroprevalence was $20.27 \%$ (CI95\%:11.11-29.43) in $2004(n=74), 25.81 \%$ (CI95\%:18.92-32.70) in $2005(n=155)$ and 19.44 (CI95\%: 11.98$26.91)$ in $2006(n=108)$, respectively. There was no significant $(p=0.34)$ difference between the yearly seroprevalences among pound dogs. Out of the 14 dogs presented with clinical signs compatible with neosporosis, 6 (43\%) were seropositive (4 with endtitre of 100,1 with endtitre of 200 and 1 with endtitre of 800 ).

\subsection{Endtitration}

The titre distribution of positive samples was analysed in relation to the origin of the dogs (Table 2). There was a significant difference $(p<0.001)$ between the populations. High titres $(\geq 1600)$ were observed mainly in group 4 (farm dogs). In this group, 21 sera out of $64(32.81 \%)$ had such a high titre.

\subsection{Immunoblot}

The presence of specific serum antibodies was confirmed by immunoblot on all positive sera in IFAT $(n=171)$. All positive sera

Table 1

$N$. caninum seroprevalences by IFAT in different dog populations from the Algiers District.

\begin{tabular}{lrrrl}
\hline Population & Negative & Positive & Total & Seroprevalence \% (CI95\%) \\
\hline 1. Pound & 261 & 76 & 337 & $22.55(18.09-27.01)^{2,3,4, a}$ \\
2. Police & 85 & 6 & 91 & $6.59(1.02-10.97)^{1,4}$ \\
3. Breeder & 184 & 25 & 209 & $11.96(7.56-16.36)^{1,4}$ \\
4. Farm & 80 & 64 & 144 & $44.44(36.33-52.56)^{1,2,3}$ \\
Total & 610 & 171 & 781 & $21.90(18.99-24.80)$ \\
\hline
\end{tabular}

CI95\%: confidence interval at 95\%. For a specific population group, superscribed numbers indicate the other group(s) which is/are significantly different from it.

${ }^{a}$ Populations with a significantly different prevalence $(p<0.01)$ 
Table 2

Distribution of IFAT titres for positive sera $(\geq 1: 50)$ in the different dog populations from the Algiers District.

\begin{tabular}{|c|c|c|c|c|c|c|}
\hline \multirow[t]{2}{*}{ Endtitre } & \multicolumn{4}{|c|}{ Number of positive per population } & \multirow{2}{*}{$\begin{array}{l}\text { Total } \\
\text { positive (\%) }\end{array}$} & \multirow[t]{2}{*}{$p$} \\
\hline & Pound & Police & Breeder & Farm & & \\
\hline 50 & 11 & 3 & 4 & 22 & 40 & $<0.0001$ \\
\hline 100 & 30 & 1 & 5 & 5 & 41 & 0.035 \\
\hline 200 & 8 & 0 & 1 & 7 & 16 & 0.0007 \\
\hline 400 & 9 & 0 & 7 & 4 & 20 & 0.41 \\
\hline 800 & 16 & 1 & 6 & 2 & 25 & $<0.0001$ \\
\hline 1600 & 2 & 1 & 2 & 21 & 29 & $<0.0001$ \\
\hline Total & 76 & 6 & 25 & 64 & 171 & $<0.001$ \\
\hline
\end{tabular}

recognized two major proteins of approximately 29-33 kDa and 40$42 \mathrm{kDa}$, respectively. Moreover the sera with endtitres $\geq 1: 200$ recognized additional proteins of $14-22,77-79,120-138$ and $180 \mathrm{kDa}$, respectively (data not shown). Some additional faint bands were sometimes visible but not in a reproducible way.

\subsection{Risk factors}

In this epidemiological study, several parameters including breed, age, sex, origin, vaccination status and clinical condition were recorded. These parameters were statistically analysed in combination with the IFAT results (Table 3).

Table 3

Risk factors.

\begin{tabular}{|c|c|c|c|c|c|c|c|c|c|}
\hline \multirow{2}{*}{$\begin{array}{l}\text { Factor } \\
\text { Age (year) }\end{array}$} & \multirow[t]{2}{*}{$N$} & \multirow[t]{2}{*}{+} & \multirow{2}{*}{$\begin{array}{l}\text { Seroprevalence \% } \\
\text { (CI95\%) }\end{array}$} & \multicolumn{6}{|c|}{ Endtitre } \\
\hline & & & & 50 & 100 & 200 & 400 & 800 & 1600 \\
\hline$<1$ & 113 & 19 & $16.81(9.92-23.71)$ & 6 & 4 & 3 & 1 & 0 & 5 \\
\hline$\geq 1-\leq 2$ & 184 & 42 & 22.83 (16.76-28.89) & 11 & 8 & 6 & 3 & 4 & 10 \\
\hline$>2-\leq 4$ & 140 & 35 & $25.00(17.83-32.17)$ & 10 & 5 & 2 & 7 & 4 & 7 \\
\hline$>4-12$ & 128 & 29 & $22.66(15.40-29.91)$ & 4 & 8 & 2 & 4 & 5 & 6 \\
\hline Total & 565 & 125 & $22.12(18.70-25.55)$ & 31 & 25 & 13 & 15 & 13 & 28 \\
\hline \multicolumn{10}{|l|}{ Sex } \\
\hline Female & 308 & 68 & $22.08(17.45-26.71)$ & 15 & 18 & 2 & 8 & 11 & 14 \\
\hline Male & 410 & 92 & $22.44(18.40-26.48)$ & 22 & 20 & 14 & 12 & 10 & 14 \\
\hline Total & 718 & 160 & $22.28(19.24-25.33)$ & 37 & 38 & 16 & 20 & 21 & 28 \\
\hline \multicolumn{10}{|l|}{ Race } \\
\hline Mongrel & 377 & 98 & 25.99 (21.57-30.42) & 18 & 32 & 12 & 8 & 14 & 14 \\
\hline $\begin{array}{c}\text { Crossed } \\
\text { bred }\end{array}$ & 120 & 37 & $30.83(22.57-39.10)$ & 12 & 4 & 1 & 5 & 5 & 10 \\
\hline Purebred & 226 & 27 & $11.95(7.72-16.18)$ & 7 & 2 & 3 & 7 & 3 & 5 \\
\hline Total & 723 & 172 & 23.79 (20.69-26.89) & 37 & 38 & 16 & 20 & 22 & 29 \\
\hline \multicolumn{10}{|l|}{ Origin } \\
\hline Imported & 35 & 1 & $2.85(6.56-13.23)$ & 0 & 0 & 0 & 0 & 1 & 0 \\
\hline Algeria & 343 & 84 & $24.48(22.22-30.37)$ & 27 & 9 & 8 & 11 & 3 & 24 \\
\hline Total & 378 & 85 & $22.49(18.28-26.70)$ & 27 & 9 & 8 & 11 & 4 & 24 \\
\hline \multicolumn{10}{|l|}{ Vaccination } \\
\hline Vaccinated & 322 & 47 & $14.60(10.74-18.45)$ & 13 & 9 & 4 & 8 & 8 & 5 \\
\hline $\begin{array}{l}\text { Not } \\
\text { vaccinated }\end{array}$ & 457 & 123 & $26.91(22.85-30.98)$ & 27 & 32 & 12 & 11 & 17 & 24 \\
\hline Total & 779 & 170 & $21.82(18.92-24.72)$ & 40 & 41 & 16 & 19 & 25 & 29 \\
\hline \multicolumn{10}{|l|}{ Aspect } \\
\hline Bad & 58 & 12 & $20.69(10.26-31.11)$ & 3 & 2 & 2 & 2 & 1 & 2 \\
\hline Average & 83 & 25 & $30.12(20.25-39.99)$ & 3 & 6 & 1 & 4 & 3 & 8 \\
\hline Good & 332 & 73 & $21.99(17.53-26.44)$ & 23 & 9 & 9 & 9 & 6 & 17 \\
\hline Total & 473 & 110 & $23.26(19.45-27.06)$ & 29 & 17 & 12 & 15 & 10 & 27 \\
\hline \multicolumn{10}{|l|}{ Season } \\
\hline Winter & 236 & 45 & $19.07(14.06-24.08)$ & 10 & 10 & 1 & 4 & 7 & 13 \\
\hline Spring & 290 & 71 & $24.48(19.53-29.43)$ & 11 & 18 & 8 & 10 & 12 & 12 \\
\hline Summer & 31 & 14 & $45.16(27.64-62.68)$ & 5 & 4 & 0 & 3 & 1 & 1 \\
\hline Autumn & 224 & 41 & $18.30(13.24-23.37)$ & 14 & 9 & 7 & 3 & 5 & 3 \\
\hline Total & 781 & 171 & $21.90(18.99-24.80)$ & 40 & 41 & 16 & 20 & 25 & 29 \\
\hline
\end{tabular}

Among de 781 dogs the data about age were available for 565 dogs. Four age classes were considered [36] : $<1$ year, $\geq 1$ to $\leq 2$ years; $>2$ to $\leq 4$ years and $>4$ years.

When considered globally, the prevalence was not related to the age $(p=0.47)$. Moreover, no significant difference $(p=0.62)$ was observed for the distribution of titres. Nevertheless, when the different dog population were considered, a significant difference was observed for breeder dogs $(p<0.05)$ and for farm dogs $(p<0.01)$.

The sex of the animals was available for 718 dogs out of 781 . Globally, no significant association $(p=0.92)$ was observed between seroprevalence and sex. At the population level, only stray dogs showed a significant association $(p<0.02)$ between sex and seroprevalence with a higher prevalence $(27.78 \%)$ in males than in females (17.34\%).

Seven hundred and twenty three dogs were classified into three categories according to their breed: purebred, cross-bred and mongrels. Globally, there was a significant association $(p<0.001)$ between seroprevalence and breed. The seroprevalence was higher in cross-bred dogs $(30.83 \%)$ than in mongrels $(25.99 \%)$ or in pure bred dogs $(11.95 \%)$. Interestingly when the different populations were considered separately no more significant association was observed $(p>0.05)$.

For dogs of known origin, a distinction was made between dogs born in Algeria $(n=343)$ and imported dogs $(n=35)$. There was a significant difference $(p<0.01)$ between the seroprevalence of these two groups. Seroprevalences in Algerian and imported dogs were $24.48 \%$ and $2.85 \%$ respectively and the difference was statistically significant $(p<0.01)$. However, it is important to note that all imported dogs were purebred police dogs.

Regarding to the distribution of the seroprevalence values in function of the season, it appeared that the seroprevalence was significantly $(p<0.01)$ higher in the summer than in another seasons (Table 3).

Seroprevalence and vaccination status were analysed for 779 dogs. There was a significant difference $(p<0.001)$ between the seroprevalence in vaccinated (14.6\%) versus non-vaccinated (26.91\%) dogs. Vaccinated dogs belonged to dog populations (police and breeders) with low seroprevalences and non-vaccinated dogs belonged to populations (pound, farm) with high seroprevalences.

Finally, a general clinical examination was performed on each dog before blood sampling. Dogs were classified in 3 categories: bad, average and good. Data were available for 473 (60.56\%) dogs. There was no significant association $(p=0.26)$ between the seroprevalence and the general clinical status.

\subsection{ELISA}

The detection of antibodies against $N$. caninum was also performed on 615 (78.75\%) sera belonging to group 1 to group 3 populations using a commercial sandwich SRS2 ELISA. Globally, the number of positive was 65 representing a seroprevalence of $10.57 \%$ (8.15-13). In comparison, the seroprevalence in IFAT on these 615 sera was $17.40 \%$ (CI95\%:14.40-20.39) which was significantly different $(p<0.01)$. Therefore, the sensitivity, the specificity and the kappa coefficient were calculated for each IFAT dilution (Table 4). Moreover, the

\section{Table 4}

Agreement between IFAT and ELISA.

\begin{tabular}{lcrrrrr}
\hline \multirow{2}{*}{ ELISA } & IFAT & \multicolumn{7}{c}{} \\
\cline { 2 - 7 } & $1 / 50$ & $1 / 100$ & $1 / 200$ & $1 / 400$ & $1 / 800$ & $1 / 1600$ \\
\hline Se (\%) & 58.5 & 59.09 & 71.70 & 72.73 & 82.14 & 40 \\
Sp (\%) & 99.4 & 97.53 & 95.20 & 94.22 & 92.84 & 89.67 \\
kappa & 0.68 & 0.63 & 0.61 & 0.55 & 0.46 & 0.04 \\
\hline
\end{tabular}

Se: sensitivity. Sp: specificity. 
Table 5

Comparison of seroprevalences by ELISA and IFAT.

\begin{tabular}{|c|c|c|c|c|c|c|c|}
\hline \multirow[t]{2}{*}{ Population } & \multirow{2}{*}{$\frac{\text { ELISA }}{\%(\mathrm{CI} 95 \%)}$} & \multicolumn{6}{|c|}{ IFAT (seroprevalence \%) } \\
\hline & & $1 / 50$ & $1 / 100$ & $1 / 200$ & $1 / 400$ & $1 / 800$ & $1 / 1600$ \\
\hline Global & $10.57(8.15-13)$ & $17.40^{\mathrm{s}}$ & $14.31^{\mathrm{ns}}$ & $8.62^{\mathrm{ns}}$ & $7.15^{\mathrm{ns}}$ & $4.55^{\mathrm{s}}$ & $0.81^{\mathrm{s}}$ \\
\hline breeder & $5.85(2.5-9.2)$ & $11.57^{\mathrm{s}}$ & $9.7^{\mathrm{s}}$ & $7.4^{\mathrm{ns}}$ & $6.9^{\text {ns }}$ & $3.7^{\mathrm{ns}}$ & $0.9^{s}$ \\
\hline Police & $4.40(1.84-8.61)$ & $6.59^{\mathrm{ns}}$ & $3.3^{\text {ns }}$ & $2.2^{\text {ns }}$ & $2.2^{\mathrm{ns}}$ & $2.2^{\mathrm{ns}}$ & $1.1^{\mathrm{s}}$ \\
\hline Stray & $\begin{array}{l}14.88 \\
(11.08-18.67)\end{array}$ & $22.61^{\mathrm{s}}$ & $19.34^{\mathrm{s}}$ & $10.42^{\mathrm{ns}}$ & $8.04^{\mathrm{s}}$ & $5.36^{\mathrm{s}}$ & $0.6^{\mathrm{s}}$ \\
\hline
\end{tabular}

s: significantly different $(p<0.05)$.

ns: not significantly different $(p \geq 0.05)$.

calculated seroprevalences for ELISA and IFAT were also compared (Table 5). It was clear that IFAT was a more sensitive method than ELISA but on the other hand at the dilution 1/200, the seroprevalences by IFAT and ELISA were not significantly different.

\subsection{Real time PCR}

Among the 100 dogs tested by PCR 34 were positive. The $\mathrm{Ct}$ value ranged from 34.5 to 46.8 , corresponding to a range from $610^{5}$ to 200 (limit of detection) equivalent-genomes per millilitre of blood. The real time PCR results were compared to IFAT results. Sixty-two dogs were negative both by PCR and IFAT, 14 blood samples were positive both by PCR and IFAT giving a relative accuracy of 76\%. Twenty sera were positive by PCR and negative by IFAT giving a relative specificity of $76 \%$ and 4 dogs were negative by PCR and positive by IFAT giving a relative sensitivity of $78 \%$. The agreement between IFAT and PCR was considered as fair (kappa $=0.4$ ) (Fig. 2). On the 100 tested blood samples, 18 showed PCR inhibition. After dilution the inhibited samples were retested and found negative.

When the PCR cut off was lowered to 45,13 sera were positive both in PCR and in IFAT; 70 sera were negative both in PCR and IFAT, 12 sera were positive in PCR and negative in IFAT and 5 sera were positive in IFAT and negative in PCR. The sensitivity and specificity was $72.2 \%$ and $85.4 \%$, respectively. A decrease in sensitivity and an increase in specificity were observed. The kappa value was 0.5 indicating that the agreement is slightly better.

Therefore, a cut off of 45 could be considered for PCR and the $\mathrm{Ct}$ values greater than 45 could be considered as doubtful.

Moreover, when the mean of $\mathrm{Ct}$ values for positive sera is plotted in function of the IFAT titre, the correlation coefficient $R^{2}$ was $80 \%$

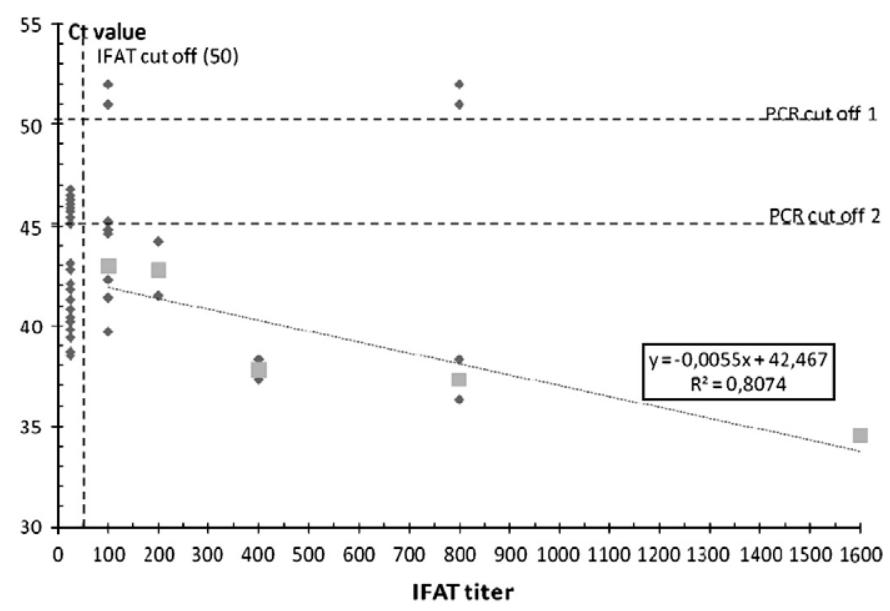

Fig. 2. Ct values in function of IFAT titres. The diamonds represent a dog either positive in PCR or in IFAT or both. The dashed horizontal lines represent the cut off values for PCR considered in this study ( 50 and 45 ). The dashed vertical line represents the cut off for IFAT (1/50). The squares represent the mean of dogs positive in PCR for each IFAT ; titre. The linear regression curve for these mean values was calculated and represented together with the equation and the $R^{2}$ value. indicating that there is some linear relation between the titre in IFAT and the $\mathrm{Ct}$ value. In other words, the higher the titre in IFAT the lower the corresponding Ct value (Fig. 2).

\section{Discussion}

Many seroprevalence studies in dogs and cattle are available for many countries [14,37]. However, this is the first epidemiological study on neosporosis in Algeria. The study was performed in the Algiers District covering around $230 \mathrm{~km}^{2}$. Several dog populations with potentially very different levels of exposure to $\mathrm{N}$. caninum were studied. IFAT was used because it is considered as a gold standard [20]. An IFAT-positive result indicates either a recent or an old infection since specific IgG can persist for years [37].

Additionally, antibodies to T. gondii, Sarcocystis spp., and Babesia canis do not cross-react with $N$. caninum tachyzoites in IFAT $[2,12,18,19]$.

On the 781 tested dogs, 171 were seropositive corresponding to an overall seroprevalence of $21.90 \%$. In comparison with other published studies, it appears that these results revealed a very high level of seroprevalence in dogs in Algeria when compared to results from Brazil (14\%) [24], Australia (9\%), Falklands Islands (0.2\%), Kenya (0\%) [38], USA and Canada (7\%) [22], and Italy (6.4\%) [39]. The seroprevalence in Algerian dogs in the present study is similar to the $29 \%$ found in another Italian survey [40].

Seroprevalences differed markedly between the different groups. The lowest seroprevalences were found in groups 2 and 3 (police squad and kennels) whereas the highest seroprevalences were found in stray and farm dogs. This is in agreement with several studies indicating that seroprevalences are higher in farm dogs or pounds dogs than in urban dogs [9,10,22-32]. In breeder (urban) dogs the seroprevalence was $12.08 \%$ which is close to the data available in similar urban dog populations [31,41]. In farm dogs the seroprevalence reached $46.24 \%$; a similar high seroprevalence in this type of dogs was also noticed by Lasri et al. [31] in Belgium. This is probably linked with the availability of infective material such as aborted fetuses and placentas [42,43]. This hypothesis is supported also by the high antibody titres recorded in farm dogs. Dijkstra et al. [44] demonstrated that the introduction of a new dog in a cattle herd increased the risk of a $N$. caninum induced abortion storm. It is hypothesised that newly introduced dogs can get infected with $N$. caninum by the consumption of infected material from chronically infected cattle and subsequently transfers the infection to other cattle through oocyst shedding. Most of stray dogs originated from periurban areas and a contact with infected cattle was likely. Moreover, the pound dogs showed similar seroprevalences during three consecutive years indicating that the level of contact with $N$. caninum was fairly constant. Nevertheless, a seasonal effect has been shown with a higher seroprevalence in the summer maybe due to a better viability and infectivity of the oocysts.

Interestingly the seroprevalence among dogs presented with symptoms compatible with neosporosis (mainly limbs paresis or ulcerous cutaneous lesions) was $43 \%$ ( 6 out of 14 ) which is similar to the seroprevalence in farm dogs. The endtitres of these dogs were not especially high except for one dog with an endtitre of 1:800 but no further investigation was performed to confirm the presence of neosporosis.

Epidemiological factors such as breed, age, sex, origin, vaccination status and body condition were evaluated. Some interesting observations were made. Globally, there were no seroprevalence differences in relation with age, sex or general clinical aspect. The absence of difference between males and females is in agreement with several studies $[10,19,38]$. However, a higher frequency in females was previously reported [6]. Interestingly, for stray dogs males were significantly more positive. 
Some studies showed significant variations of seroprevalence in relation with the age of dogs with a decrease of seroprevalence and titres in older dogs [6]. Globally, this was not the case in the present study but for farm dogs were dogs between 1 and 2 years or upper than 4 years were more positive. The lower seroprevalence in imported dogs was probably biased as all of them were pure breed police dogs. The results for the breed were interesting since when the results were considered globally there was an effect with a higher prevalence in crossed breed but at the population level this effect was not present. Finally, the vaccination status was also a significant factor since vaccinated dogs were less frequently seropositive than nonvaccinated dogs. This point can probably be related to better hygienic conditions and care in vaccinated dogs. Nevertheless, by definition vaccination stimulates the immune system which can maybe lead to a better immunological answer to another not related pathogen by adjuvant effect.

The sera positive in IFAT were confirmed by immunoblotting using a crude $N$. caninum soluble antigen. The immunodominant proteins had a molecular weight of 14-22, 29-33, 40-42, 77-79, 66, 120-138 and $180 \mathrm{kDa}$. The 29-33 and 40-42 kDa proteins corresponded most probably to the two major surface antigens NcSAg1 and NcSRS2, respectively [45]. The $14-22 \mathrm{kDa}$ band had a molecular weight compatible with Gra7 antigen [46]. The heaviest bands (120-138 and $180 \mathrm{kDa}$ ) were maybe due to an incomplete protein denaturation. Seroprevalences observed in ELISA were significantly lower than those observed in IFAT. Nevertheless, for ELISA the sera were diluted $1 / 100$ and for IFAT the dilution started at $1 / 50$. But even at $1 / 100$ the sensitivity was low (59\%) underlined the fact that ELISA was less sensitive than IFAT. But when compared to the results of IFAT at $1 / 200$ the results of ELISA were comparable since the observed prevalence were not significantly different and that the sensitivity and the specificity were upper than $70 \%$ with a kappa value upper than 0.61 considered as good [47].

The most remarkable observation was a marked and significant difference between seroprevalence and real time PCR results in 100 dogs enrolled in the study. Several explanations can be proposed. Serology is an indirect way to study exposure of dogs to N. caninum. The IFAT as used in the present and other studies detects the presence of IgG antibodies. In recently infected dogs this technique may give a negative result if IgM are not looked for. Additionally all serological available techniques use $N$. caninum tachyzoites grown in cell culture as antigenic source and IFAT detects mainly the major surface antigens present on the tachyzoite surface. However, major antigenic differences do exist between the different stages of $N$. caninum i.e. the tachyzoite, the bradyzoite and the oocyst $[48,49]$. These three stages can be observed in the dog. Consequently the detection of IFATpositive reactions against $N$. caninum tachyzoites in dog sera may be of little significance regarding the presence of bradyzoite-containing tissue cysts or the past or present shedding of oocysts in a given animal. Such reactions indicate only that the respective animal is or was an intermediate host of $N$. caninum [50]. For example in many studies the majority of dogs with a history of shedding oocysts showed no seroconversion with respect to $N$. caninum tachyzoite surface antigens examined by IFAT or NAT. This was also confirmed by immunoblot-based techniques both in naturally and experimentally infected dogs [50,51]. Three out of the 4 sera which were positive in IFAT and negative in PCR showed PCR inhibition.

A real time PCR was used previously to detect $N$. caninum in bovine blood samples either in aborted or pregnant cows [52,53]. The relative amount of $N$. caninum DNA in the blood of aborted cows decreased after abortion whereas increasing amounts were detected during pregnancy. These changes could be related to a reactivation of tissue cysts leading to parasitaemia. However these authors did not compare their results to serology and the reactivation of tissue cysts in the dog has not been documented. Additionally the reproductive status of the dogs enrolled in the present study was unknown.
Moreover, the number of positive cattle was higher by PCR on sera than by IFAT (McInnes et al., 2006 [54]) which is in agreement with our results.

Similar findings were recorded in another host-parasite relationship in the dog. For example in areas endemic for canine leishmaniosis (Leishmania infantum) in the Mediterranean basin studies using PCR have confirmed that the prevalence of infection in dogs is much higher than the proportion that actually develops symptomatic disease or even specific antibodies [55,56]. By instance in 73 clinically healthy hunting dogs in Greece, $12.3 \%$ tested positive by using serology, whereas $63 \%$ tested positive by PCR [57]. These observations suggest that serology and PCR are measuring different aspects of the host-parasite relationship of canine neosporosis. Another explantation for dogs positive by PCR but negative by IFAT is that since vertical transmission is efficient in dog [58], the naive infected fetus could consider $N$. caninum as self antigen and would develop an immunotolerance leading to seronegativity but PCR positive at the adult stage.

In conclusion, this study indicates that dogs in the Algiers District are highly exposed to $N$. caninum and that farm and stray dogs are significantly more exposed than other categories living in an urban environment (police and kennel dogs). This is in agreement with most of the similar studies conducted in other countries. The presence of dogs in farms as a risk factor for cattle abortion must be investigated. Additional investigations in cattle are needed but neosporosis should be included in the differential diagnosis of canine neurological disorders and cattle abortion in the studied area.

\section{Acknowledgments}

F Ghalmi was supported by a mixed grant from the Algerian Ministry of Higher Education and by the Belgian Technical Cooperation, (BTC) Brussels, Belgium.

The authors thank Dr Esther Kissling from the Scientific Institute of Public Health (IPH) for critical reading and statistical support and Misses Azzag, Bouabdallah, Rebouh and Remichi for their technical help during serum sampling.

\section{References}

[1] Dubey JP. Neosporosis in cattle. Vet Clin North Am Food Anim Pract 2005;21: 473-83

[2] Dubey JP, Lindsay DS. A review of Neospora caninum and neosporosis. Vet Parasitol 1996;67:1-59.

[3] Lindsay DS, Dubey JP, Duncan RB. Confirmation that the dog is a definitive host for Neospora caninum. Vet Parasitol 1999;82:327-33.

[4] Paré J, Thurmond MCC, Hietala K. Congenital Neospora caninum infection in dairy cattle and associated calfhood mortality. Can J Vet Res 1996;60:133-9.

[5] Schares G, Peters M, Wurm R, Bärwald A, Conraths FJ. The efficiency of vertical transmission of Neospora caninum in dairy cattle analysed by serological techniques. Vet Parasitol 1998;80:87-98.

[6] Wouda W, Dijkstra T, Kramer AMH, van Maanen C, Brinkhof JMA. Seroepidemiological evidence for a relationship between Neospora caninum infections in dogs and cattle. Int J Parasitol 1999;29:1677-82.

[7] Gondim LFP, McAllister MM, Pitt WC, Zemlicka DE. Coyotes (Canis latrans) are definitive hosts of Neospora caninum. Int J Parasitol 2004;34:159-61.

[8] Paré J, Fecteau G, Fortin M, Marsolais G. Seroepidemiologic study of Neospora caninum in dairy herds. J Am Vet Med Ass 1998;213:1595-8.

[9] Mainar-Jaime RC, Thurmond MCB, Berzal-Herranz BB, Hietala SK. Seroprevalence of Neospora caninum and abortion in dairy cows in northern Spain. Vet Rec 1999;145: $72-5$.

[10] Sawada M, Park CH, Kondo H. Serological survey of antibody to Neospora caninum in Japanese dogs. J Vet Med Sc 1998;60:853-4.

[11] Ferroglio E, Pasino M, Ronco F, Benà A, Trisciuogli A. Seroprevalence of antibodies to Neospora caninum in urban and rural dogs in north-west Italy. Zoonoses Public Health 2004;54:135-9.

[12] Dubey JP, Lindsay DS. Neosporosis. Parasitol Tod 1993;9:452-8.

[13] Dubey JP, Schares G, Ortega-Mora LM. Epidemiology and control of neosporosis and Neospora caninum. Clin Microbiol Rev 2007;20:323-67.

[14] Ghalmi F, China B, Losson B. Diagnostic et surveillance épidémiologique de Neospora caninum. Ann Méd Vét 2007;151:123-49.

[15] Packham AE, Sverlow KW, Conrad PA, Loomis EF, Rowe JD, Anderson ML, et al. A modified agglutination test for Neospora caninum: development, optimization, and comparison to the indirect fluorescent-antibody test and enzyme-linked immunosorbent assay. Clin Diagn Lab Immunol 1998;5:467-73. 
[16] Dubey JP, Hattel AL, Lindsay DS, Topper MJ. Neonatal Neospora caninum infection in dogs: isolation of the causative agent and experimental transmission. J Am Vet Med Assoc 1988;193:1259-63.

[17] Lindsay DS, Dubey JP. Immunohistochemical diagnosis of Neospora caninum in tissue sections. Am J Vet Res 1989;50:1981-3.

[18] Dubey JP, Alvarado-Esquivel C, Liesenfeld O, Herrera-Flores RG, Ramírez-Sánchez BE, González-Herrera A, et al. Neospora caninum and Toxoplasma gondii antibodies in dogs from Durango City, Mexico. J Parasitol 2007;93:1033-5.

[19] Trees AJ, Guy F, Tennant BJ, Balfour AH, Dubey JP. Prevalence of antibodies to Neospora caninum in a population of urban dogs in England. Vet Rec 1993;132: 125-6.

[20] Capelli G, Natale A, Nardelli S, Frangipane di Regalbono A, Pietrobelli M. Validation of a commercially available cELISA test for canine neosporosis against an indirect fluorescent antibody test (IFAT). Prev Vet Med 2006;73:315-20.

[21] Ghalmi F, China B, Kaidi R, Daube G, Losson B. Detection of Neospora caninum in dog organs using real time PCR systems. Vet Parasitol 2008;155:161-7.

[22] Cheadle MA, Lindsay DS, Blagburn BL. Prevalence of antibodies to Neospora caninum in dogs. Vet Parasitol 1999;85:325-30.

[23] Basso W, Venturini L, Venturini MC, Hill DE, Kwok OC, Shen SK, et al. First isolation of Neospora caninum from the feces of a naturally infected dog. J Parasitol 2001;87: 612-8.

[24] Fernandes BCTM, Gennari SM, Souza SLP, Carvalho JM, Oliveira WG, Cury MC Prevalence of anti-Neospora caninum antibodies in dogs from urban, periurban and rural areas of the city of Uberlàndia, Minas Gerais, Brazil. Vet Parasitol 2004;123: 33-40.

[25] de Moraes CC, Megid J, Pituco EM, Okuda LH, Del Fava C, de Stefano E, et al. Occurrence of antibodies anti-Neospora caninum in dogs of Botucatu range Micro region, State of São Paulo, Brazil. Rev Bras Parasitol Vet 2008;17:1-6.

[26] Cruz-Vázquez C, Medina-Esparza L, Marentes A, Morales-Salinas E, GarciaVázquez Z. Seroepidemiological study of Neospora caninum infection in dogs found in dairy farms and urban areas of Aguascalientes, Mexico. Vet Parasitol 2008;157:139-43.

[27] Sharma S, Bal MS, Meenakshi, Kaur K, Sandhu KS, Dubey JP. Seroprevalence of Neospora caninum antibodies in dogs in India. J Parasitol 2008;94:303-4.

[28] Malmasi A, Hosseininejad M, Haddadzadeh H, Badii A, Bahonar A. Serologic study of anti-Neospora caninum antibodies in household dogs and dogs living in dairy and beef cattle farms in Tehran, Iran. Parasitol Res 2006;100:1143-5.

[29] Antony A, Williamson NB. Prevalence of antibodies to Neospora caninum in dogs of rural or urban origin in central New Zealand. N Z Vet J 2003;51:232-7.

[30] Collantes-Fernández E, Gómez-Bautista M, Miró G, Alvarez-García G, PereiraBueno J, Frisuelos C, et al. Seroprevalence and risk factors associated with Neospora caninum infection in different dog populations in Spain. Vet Parasitol 2008;152: $148-51$.

[31] Lasri S, De Meerschman F, Rettigner C, Focant C, Losson B. Comparison of three techniques for the serological diagnosis of Neospora caninum in the dog and their use for epidemiological studies. Vet Parasitol 2004;123:25-32.

[32] Vaclavek P, Sedlàk K, Hurkovà LL, Vodràzka P, Sebesta R, Koudela B. Serological survey of Neospora caninum in dogs in the Czech Republic and a long-term study of dynamics of antibodies. Vet Parasitol 2007;143:35-41.

[33] Silva DA, Lobato J, Mineo TW, Mineo JR. Evaluation of serological tests for the diagnosis of Neospora caninum infection in dogs: optimization of cut off titers and inhibition studies of cross-reactivity with Toxoplasma gondii. Vet Parasitol 2007;143: 234-44.

[34] Ghalmi F, China B, Kaidi R, Losson B. Evaluation of a SRS2 sandwich commercial enzyme-linked immunosorbent assay for the detection of anti-Neospora caninum antibodies in bovine and canine sera. J Vet Diagn Invest 2009;21:108-11.

[35] Rettigner C, Lasri S, De Meerschman F, Focant C, Beckers JF, Losson B. Immune response and antigen recognition in non-pregnant ewes experimentally infected with Neospora caninum tachyzoites. Vet Parasitol 2004;122:261-71.

[36] de Souza SL, Guimarães Jr JS, Ferreira F, Dubey JP, Gennari SM. Prevalence of Neospora caninum antibodies in dogs from dairy cattle farms in Parana, Brazil. J Parasitol 2002;88:408-9.

[37] Björkman C, Uggla A. Serological diagnosis of Neospora caninum infection. Int ] Parasitol 1999;29:1497-507.
[38] Barber JS, GasserRB EllisJ, Reichel MP, McMillan D, Trees AJ. Prevalence of antibodies to Neospora caninum in different canid populations. J Parasitol 1997;83: 1056-8

[39] Cringoli G, Rinaldi E, Capuano F, Baldi L, Veneziano V, Capelli G. Serological survey of Neospora caninum and Leishmania infantum co-infection in dogs. Vet Parasitol 2002;106:307-13.

[40] Cringoli G, Capuano FF, Veneziano VV, Romano L, Solimene R, Barber JS, et al. Prevalence of antibodies against Neospora caninum in dog sera. Parasitologia 1996;38:282.

[41] Barber JS, Van Polis I, Trees AJ, Ham L. Seroprevalence of antibodies to Neospora caninum in Belgian dogs. J Sm Anim Pract 1997;38:115-6.

[42] Shivaprasad HL, Ely R, Dubey JP. A Neospora-like protozoon found in an aborted bovine placenta. Vet Parasitol 1989;34:145-8.

[43] Dijkstra T, Eysker M, Schares G, Conrath FG, Wouda W, Barkema HW. Dogs shed Neospora caninum oocysts after ingestion of naturally infected bovine placenta but not after ingestion of colostrum spiked with Neospora caninum tachyzoites. Int J Parasitol 2001;31:747-52.

[44] Dijkstra T, Barkema HW, Eysker M, Hesselink JW, Wouda W. Natural transmission routes of Neospora caninum between farm dogs and cattle. Vet Parasitol 2002;105: 99-104.

[45] Pinheiro AM, Costa MF, Paule B, Vale V, Ribeiro M, Nascimento I, et al. Serologic immunoreactivity to Neospora caninum antigens in dogs determined by indirect immunofluorescence, western blotting and dot-ELISA. Vet Parasitol 2005;130: 73-9.

[46] Alvarez-Garcia G, Pitarch A, Zaballos A, Fernandez-Garcia C, Gil M, Gomez-Bautista $\mathrm{M}$, et al. The NcGra7 gene encodes the immunodominant $17 \mathrm{kDa}$ antigen of Neospora caninum. Parasitol 2007; 134:41-50.

[47] Cohen J. A coefficient of agreement for nomimal scales. Educ Psychol Meas 1960;20 2746.

[48] Fuchs N, Sonda S, Gottstein BB, Hemphill A. Differential expression of cell-surfaceand dense granule-associated Neospora caninum proteins in tachyzoite and bradyzoites. J Parasitol 1998;84:753-8.

[49] Vonlaufen N, Guetg N, Naguleswaran A, Müller N, Björkman C, Schares G, et al. In vitro induction of Neospora caninum bradyzoites in vero cells reveals differential antigen expression, localization, and host-cell recognition of tachyzoites and bradyzoites. Infect Immun 2004;72:576-83.

[50] Schares G, Losson B. Aetiological diagnosis. In: Ortega-Mora LM, Gottstein B, Conraths FJ, Buxton D, editors. Protozoal abortion in farm ruminants. Wallingford, UK: Cabi; 2007. p. 98-103.

[51] Schares G, Pantchev N, Barutzki D, Heydorn AO, Bauer C, Conraths FJ. Oocysts of Neospora caninum, Hammondia heydorni, Toxoplasma gondii and Hammondia hammondi in faeces collected from dogs in Germany. Int J Parasitol 2005;35: $1525-7$.

[52] Okeoma CM, Stowell KM, Williamson NB, Pomroy WE. Neospora caninum: quantification of DNA in the blood of naturally infected aborted and pregnant cows using real-time PCR. Exp Parasitol 2005;110:48-55.

[53] Okeoma CM, Williamson NB, Pomroy WE, Stowell KM, Gillespie L. The use of PCR to detect Neospora caninum DNA in the blood of naturally infected cows. Vet Parasitol 2004;122:307-15.

[54] McInnes LM, Ryan UM, O'Handley R, Sager H, Froshaw D, Palmer DG. Diagnostic significance of Neospora caninum DNA detected by PCR in cattle serum. Vet Parasitol 2006;142:207-13.

[55] Berrahal F, Mary C, Roze M, Berenger A, Escoffier K, Lamouroux D, et al. Canine leishmaniasis: identification of asymptomatic carriers by polymerase chainreaction and immunoblotting. Am J Trop Med Hyg 1996;55:273-7.

[56] Solano-Gallego LL, Morell P, Arboix M, Alberola J, Ferrer L. Prevalence of Leishmania infantum infection in dogs living in an endemic area of canine leishmaniasis endemicity using PCR on several tissues and serology. J Clin Microbiol 2001;39: 560-3.

[57] Leontides LS, Saridomichelakis MN, Billinis C, Kontos V, Koutinas AF, Galatos AD, et al. A cross-sectional study of Leishmania spp. infection in clinically healthy dogs with polymerase chain reaction and serology in Greece. Vet Parasitol 2002;109:19-27.

[58] Barber JS, Trees AJ. Naturally occurring vertical transmission of Neospora caninum in dogs. Int J Parasitol 1998;28:57-64. 